\title{
Intermediate gastropod hosts of major feline cardiopulmonary nematodes in an area of wildcat and domestic cat sympatry in Greece
}

\author{
Dimitris Dimzas ${ }^{1}$, Simone Morelli², Donato Traversa², Angela Di Cesare², Yoo Ree Van Bourgonie ${ }^{3}$, \\ Karin Breugelmans ${ }^{3}$, Thierry Backeljau ${ }^{3,4}$, Antonio Frangipane di Regalbono ${ }^{5}$ and Anastasia Diakou ${ }^{1 *}$ (D)
}

\begin{abstract}
Background: The metastrongyloid nematodes Aelurostrongylus abstrusus, Troglostrongylus brevior and Angiostrongylus chabaudi are cardiopulmonary parasites affecting domestic cats (Felis catus) and wildcats (Felis silvestris). Although knowledge on these nematodes has been improved in the past years, gaps in our knowledge of their distribution and role of gastropods as intermediate hosts in Europe still exist. This study reports on the presence of these nematodes and their intermediate hosts in an area in Greece where domestic cats and wildcats occur in sympatry.

Methods: Terrestrial gastropods were collected in the field and identified morphologically and by mitochondrial DNA-sequence analysis. Metastrongyloid larvae were detected by artificial digestion, morphologically identified to the species and stage level and their identity was molecularly confirmed.

Results: Aelurostrongylus abstrusus was found in the snails Massylaea vermiculata and Helix lucorum, T. brevior in the slug Tandonia sp., and A. chabaudi in the slug Limax sp. and the snails H. lucorum and M. vermiculata.

Conclusions: To the best of our knowledge this study provides the first reports of (i) terrestrial gastropods being naturally infected with A. chabaudi, (ii) T. brevior naturally infecting terrestrial gastropods in Europe, and (iii) A. abstrusus naturally infecting terrestrial gastropods in Greece. Furthermore, the present study describes for the first time developmental stages of A. chabaudi and T. brevior in naturally infected gastropods. The biological characteristics of various intermediate gastropod hosts that could influence the distribution and expansion of feline cardiopulmonary nematodes are discussed, along with epizootiological implications and perspectives.
\end{abstract}

Keywords: Aelurostrongylus abstrusus, Angiostrongylus chabaudi, Cardiopulmonary parasites, Domestic cat, Gastropods, Slugs, Snails, Troglostrongylus brevior, Wildcat

\section{Background}

Three nematodes belonging to the superfamily Metastrongyloidea (order Strongylida), i.e. Aelurostrongylus abstrusus, Troglostrongylus brevior and Angiostrongylus chabaudi, are cardiopulmonary parasites affecting the domestic cat (Felis catus), the European wildcat (Felis

\footnotetext{
*Correspondence: diakou@vet.auth.gr

1 School of Veterinary Medicine, Faculty of Health Sciences, Aristotle University of Thessaloniki, 54124 Thessaloniki, Greece

Full list of author information is available at the end of the article
}

silvestris) and other wild felids [1,2]. The life-cycle of these parasites is indirect: felines shed first-stage larvae (L1) that continue their development in a terrestrial gastropod mollusc to develop to second-stage (L2), and subsequently third-stage (L3) larvae, that is infective for the definitive host; paratenic hosts (small vertebrates) also play an important role in the biological cycle of these nematodes $[1,3]$. Because of their veterinary significance and apparently expanding distribution both

c) The Author(s) 2020. This article is licensed under a Creative Commons Attribution 4.0 International License, which permits use, sharing, adaptation, distribution and reproduction in any medium or format, as long as you give appropriate credit to the original author(s) and the source, provide a link to the Creative Commons licence, and indicate if changes were made. The images or other third party material in this article are included in the article's Creative Commons licence, unless indicated otherwise in a credit line to the material. If material is not included in the article's Creative Commons licence and your intended use is not permitted by statutory regulation or exceeds the permitted use, you will need to obtain permission directly from the copyright holder. To view a copy of this licence, visit http://creativeco mmons.org/licenses/by/4.0/. The Creative Commons Public Domain Dedication waiver (http://creativecommons.org/publicdomain/ zero/1.0/) applies to the data made available in this article, unless otherwise stated in a credit line to the data. 
in enzootic and previously non-enzootic regions, these parasites are gaining scientific interest $[1,4-8]$.

Aelurostrongylus abstrusus (Railliet, 1898) ("cat lungworm") affects domestic cats worldwide and is considered the major felid respiratory parasite $[1$, 9]. Nevertheless, during the last few years a different lungworm, i.e. T. brevior, traditionally considered to be associated only with wild felids, has been increasingly reported in domestic cats [7]. This lungworm was described in 1949 in wild felids from Palestine [10] and later recorded in wildcats in central Italy [11]. In the 21st century, T. brevior has been reported in domestic cats from various Mediterranean islands, i.e. Ibiza, Sicily, Sardinia, Crete, Mykonos, Skopelos and Cyprus (see Crisi et al. [7] for details) but also in continental Europe, i.e. Italy [12], Greece [13], Bosnia and Herzegovina [14], Bulgaria, Spain [15] and Romania [16].

In contrast, very little is known about $A$. chabaudi causing feline angiostrongylosis, first identified in European wildcats from central Italy [17]. Since the original description, this parasite has never been reported until recently, when immature adult specimens were found in two domestic cats in Italy $[5,6]$. Recently, $A$. chabaudi has been reported in wildcats from Greece, Romania, Bulgaria, Italy and Bosnia and Herzegovina [2, 18-21].

The detection of $A$. abstrusus, $T$. brevior and $A$. chabaudi in both wildcats and domestic cats, along with many other pathological, clinical and molecular data $[1,22,23]$, indicate possible routes of cross transmission between these feline species, especially in areas where domestic cats and wildcats co-exist. For example, infections with $T$. brevior in domestic cats are mostly documented in areas within the distributional range of wildcats [6, 24-26]. Analogously, A. abstrusus may also infect wildcats in regions with high prevalence in domestic cat populations [12, 21, 23]. Important factors related to the circulation and transmission of these parasites are the distribution and biological features of their intermediate hosts, i.e. terrestrial snails and slugs. These nematodes reach the infective stage in various gastropod species under experimental conditions [27-30]. Furthermore, there are some reports of gastropods naturally infected with $A$. abstrusus and T. brevior [31-39]. Conversely, natural infections of gastropods with $A$. chabaudi have not yet been documented, leaving an important gap in the poorly-known life-cycle of this parasite.

In this context, there is a merit in improving knowledge on the role of different mollusc species implicated in the transmission of these parasites to wildcats and domestic cats in natural environments, especially in areas where both felines occur in sympatry. Such data would help to predict the geographical spread of lungworms based on the distribution of their intermediate hosts. Thus, the aim of the present study was to investigate slugs and snails in areas where they could act as the interface for the spillover of metastrongyloid infections between the two felines. Herein we report the first cases of gastropod natural intermediate hosts of feline metastrongyloid nematodes, found in the frame of a larger, ongoing project investigating terrestrial gastropods as intermediate hosts of nematode parasites in Greece.

\section{Methods}

\section{Study area and sample collection}

The gastropods were sampled as a part of an ongoing project investigating terrestrial gastropods as intermediate hosts of parasitic nematodes in Greece. The specimens were collected in five sub-urban, rural and wild habitats (sites A-E, Fig. 1), where wildcats and domestic cats co-exist, in order to investigate slugs and snails in areas where they could act as the interface for the spillover of metastrongyloid infections between the two felines. More precisely, site A (sub-urban area of the city of Kozani), is an area with few houses and plenty of vegetation (grasses, trees, etc.), characterised by a continental climate with dry, cold winters, an average yearly temperature of $13{ }^{\circ} \mathrm{C}$ and a relative humidity of $74 \%$ [40]. Site B is a typical rural environment at the village Vyronia, and sites $\mathrm{C}, \mathrm{D}$ and $\mathrm{E}$ are close to three important wetlands (Lakes Kerkini, Koronia and Volvi, respectively), that are considered wild habitats, however close to human activities. The climate at Vyronia and around the lakes is a semi-arid Mediterranean climate, with mild to cold winters, an average yearly temperature of $15{ }^{\circ} \mathrm{C}$ and annual rainfall between $600-650 \mathrm{~mm}$ [40].

Gastropods (both active and hibernating/estivating) were collected by hand from the study areas, placed individually in small plastic bags and tagged with a code that corresponded to a form with the details of the collection (date, coordinates and type of environment). The present data are derived from the examination of 25 snails (8, 7, 3 and 7 from sites $A, B, C$ and $D$, respectively) and 25 slugs $(1,8,11$ and 5 from cites $\mathrm{A}, \mathrm{B}, \mathrm{C}$ and $\mathrm{E}$, respectively) as preliminary results of the aforementioned broader study. All specimens were cryo-euthanised immediately in a deep freezer and stored frozen at $-20{ }^{\circ} \mathrm{C}$ until further examination.

\section{Identification of gastropods}

For each examined gastropod, individual photographs were used for morphological assessment and foot tissue sampling $\left(c .2 \mathrm{~mm}^{3}\right)$ for DNA-based identification. Furthermore, from each sampling spot whole specimens with the same phenotype were collected and conserved in $70 \%$ ethanol for morphological confirmation. The 
nomenclature of the molluscs applied follows MolluscaBase [41].

DNA-based identification of gastropods was performed on infected specimens and relied on two mtDNA fragments, i.e. the cytochrome $c$ oxidase subunit 1 (cox1) barcode and $16 S$ ribosomal DNA (16S). Genomic DNA was extracted with the Nucleospin ${ }^{\circledR}$ Tissue Kit (MachereyNagel, Düren, Germany) according to the manufacturer's instructions. The cox 1 fragment was PCR amplified using the primers LCO1490 (forward) and HCO2198 (reverse) [42] and $16 \mathrm{~S}$ using the primers $16 \mathrm{Sar}$ (forward) and 16Sbr (reverse) [43]. PCR was carried out in $12.5 \mu \mathrm{l}$ reaction volumes containing $0.25 \mu \mathrm{l}$ of dNTP mix (containing $10 \mathrm{mM}$ of each dNTP), $1.25 \mu \mathrm{l}$ of $2 \mu \mathrm{M}$ of each primer, $0.05 \mu \mathrm{l}$ of $10 \mathrm{U} / \mu \mathrm{l}$ Platinum ${ }^{\circledR}$ Taq DNA Polymerase (Thermo Fisher Scientific, Waltham, USA), $1.25 \mu \mathrm{l}$ of $10 \times$ PCR buffer, $0.375 \mu \mathrm{l}$ of $50 \mathrm{mM}$ of $\mathrm{MgCl}_{2}, 1 \mu \mathrm{l}$ of DNA extract and sterile ultra-pure water to a volume of $12.5 \mu \mathrm{l}$. All amplifications included positive (slugs of the genus Arion) and negative controls. The PCR cycling conditions followed the protocol of Rowson et al. [44]: (i) initial denaturation for $150 \mathrm{~s}$ at $94{ }^{\circ} \mathrm{C}$; (ii) 40 cycles of $30 \mathrm{~s}$ at $94{ }^{\circ} \mathrm{C}, 45 \mathrm{~s}$ at $47{ }^{\circ} \mathrm{C}$, and $75 \mathrm{~s}$ at $72{ }^{\circ} \mathrm{C}$; and (iii) a final extension step at $72{ }^{\circ} \mathrm{C}$ for $10 \mathrm{~min}$. Amplification products were visualised under UV light on a 1\% Midori Green-stained (Nippon Genetics Europe, Düren, Germany) agarose electrophoresis gel.

Samples that did not yield a visible amplification product were subjected to a new PCR reaction carried out in $11 \mu \mathrm{l}$ reaction volumes containing $5.5 \mu$ l of Qiagen ${ }^{\circledR}$ Multiplex PCR Master Mix containing HotStarTaq ${ }^{\circledR}$ DNA Polymerase, Multiplex PCR Buffer with $6 \mathrm{mM} \mathrm{MgCl} 2$ and dNTP mix (Qiagen, Venlo, The Netherlands), $1 \mu \mathrm{l}$ of $2 \mu \mathrm{M}$ of each primer, $1 \mu \mathrm{l}$ of DNA extract and sterile ultra-pure water to a volume of $11 \mu \mathrm{l}$. All amplifications included positive (slugs of the genus Arion) and negative controls. The PCR cycling conditions were: (i) initial denaturation for $900 \mathrm{~s}$ at $95{ }^{\circ} \mathrm{C}$; (ii) 40 cycles of $30 \mathrm{~s}$ at 94 ${ }^{\circ} \mathrm{C}$, $30 \mathrm{~s}$ at $45^{\circ} \mathrm{C}$, and $60 \mathrm{~s}$ at $72{ }^{\circ} \mathrm{C}$; and (iii) a final extension step at $72{ }^{\circ} \mathrm{C}$ for $10 \mathrm{~min}$. Amplification products were visualised under UV light on a $1 \%$ Midori Greenstained agarose electrophoresis gel.

PCR amplicons were purified using the ExoSAP ${ }^{\mathrm{TM}}$ mixture (Thermo Fisher Scientific) according to the manufacturer's instructions. DNA sequencing reactions (both directions) were performed using BigDye ${ }^{\mathrm{TM}}$ Terminator v3.1 Cycle Sequencing Kit (Thermo Fisher Scientific) and an ABI 3130xl capillary DNA sequencer.

DNA sequences were checked, assembled, corrected and trimmed using Geneious Prime (https://www.genei ous.com/). Using the Basic Local Alignment Search Tool for nucleotides (BLASTn) of GenBank, the $16 S(n=29)$ and $\operatorname{cox} 1(n=31)$ sequences generated were compared to those in GenBank and the Barcode of Life Data-Identification System (IDS-BOLD) in BOLD, respectively. $16 \mathrm{~S}$ and $\operatorname{cox} 1$ sequences were subsequently aligned separately in Geneious Prime. Each dataset included all generated sequences, and a selection of sequences (depending on the number of available reference sequences) of congeneric species retrieved from GenBank and BOLD. Geneious Prime was also used to infer amounts of sequence divergence by calculating $\mathrm{p}$ - and Tamura-Nei distances based on pairwise deletion of indels and to reconstruct Neighbor-Joining (NJ) trees. The reliability of tree nodes was assessed by bootstrapping with 1000 replicates. Boettgerilla pallens Simroth, 1912 (Boettgerillidae) and Theba pisana (Müller, 1774) (Helicidae) were used as outgroups for NJ trees of slugs and snails, respectively. DNA species identifications were based on percentage of sequence homology and the NJ-tree clustering position of the generated sequences relative to GenBank or BOLD reference sequences.

\section{Detection of metastrongyloid larvae in gastropods}

Gastropods were removed from the freezer, left to thaw at room temperature and processed by artificial digestion as previously described with slight modifications [45]. Briefly, each gastropod was weighed (after removal of the shell in the case of snails), minced with a scalpel blade and placed in an Erlenmeyer flask with digestive fluid that contained $0.05 \mathrm{~g}$ pepsin 2000FIP, $0.04 \mathrm{~g} \mathrm{NaCl}$, $0.13 \mathrm{ml} \mathrm{HCl}$ and $5.5 \mathrm{ml}$ tap water per gram of tissue. The samples were digested in a magnetic stirrer at $1000 \times$ rpm and at $34-37^{\circ} \mathrm{C}$ for $75 \mathrm{~min}$. Subsequently, the digestion fluid was poured through a $180 \mu \mathrm{m}$ sieve in a coneshaped glass recipient of 11 to which tap water was added to stop the digestion procedure. The recipient was left for at least $3 \mathrm{~h}$ or overnight in the fridge, to allow precipitation. The supernatant was discarded, and the precipitate was transferred to conical glass tubes and centrifuged at $200 \times g$ for $5 \mathrm{~min}$. The supernatant was discarded, and the precipitate was examined under a light microscope at $45 \times, 100 \times$ and $400 \times$ magnifications. Metastrongyloid larvae were identified according to morphological and morphometric characteristics $[10,18,28,29,46]$. The larvae were collected individually under a stereomicroscope and stored per gastropod specimen and per species in Eppendorf tubes with absolute ethanol for subsequent DNA-based species identification.

To confirm the identity of the larvae, a triplex seminested PCR was performed as previously described [47]. DNA extraction was carried out using a commercial kit (i.e. Qiagen Stool Mini Kit, Qiagen, Hilden, Germany). Briefly, the first step with universal primers $\mathrm{NC1}$ and 




Fig. 1 Areas of Greece where terrestrial gastropods infected with feline metastrongyloids where collected. A, Kozani (Aelurostrongylus abstrusus in Helix lucorum); B, Vyronia (A. abstrusus in Massylaea vermiculata); C, Lake Kerkini (Troglostrongylus brevior in Tandonia cf. sowerbyi); D, Lake Koronia (Angiostrongylus chabaudi in H. lucorum and M. vermiculata); E, Lake Volvi (A. chabaudi in Limax cf. conemenosi)

$\mathrm{NC} 2$ was performed. In the second step primers specific for A. abstrusus (AabFor: 5'-GTA ACA ACG ATA TTG GTA CTA TG-3'), T. brevior (TbrFor: 5'-CGG TGA TTG ATA ATG ATG CAT-3'), and A. chabaudi were used in combination with $\mathrm{NC} 2$ to achieve specific amplifications of $\sim 326$-bp-, $\sim 520$-bp-, and $\sim 200$-bp-long fragments, respectively. A negative-control sample containing all of the reaction reagents with sterile distilled water to substitute for the template was added to each PCR run. All amplifications have been carried out as previously described [47]. Amplicons were electrophoresed on a $1.8 \%(\mathrm{wt} / \mathrm{vol})$ agarose gel, stained with GelRed 10,000× (Biotium Inc., Fremont, USA).

The amplicons were purified using a QIAquick gel extraction kit (Qiagen) and then sequenced directly sing BigDye Terminator v.3.1 chemistry (Applied Biosystems, Massachusetts, USA). Sequences were determined in both strands, aligned, and then compared with those of metastrongyloids available in GenBank using BLAST (http://www.ncbi.nlm.nih.gov/BLAST).

\section{Results}

Seven out of $50(14 \%)$ gastropods, i.e. 4 snails and 3 slugs, were found infected with feline metastrongyloids (Table 1). More precisely, 1 out of 8,1 of 7 and 2 of 7 snails from Kozani, Vyronia and Koronia Lake, and 1 out of 11 and 2 of 5 slugs from sites Kerkini Lake and Volvi Lake, respectively, were found infected.

\section{Identification of gastropods and infection detected in each gastropod}

One snail from Vyronia and one from the area of Lake Koronia were identified as Massylaea vermiculata (Müller, 1774). One snail from Kozani and one collected near Lake Koronia were identified as Helix lucorum Linnaeus, 1758. One slug collected near Lake Kerkini was identified as 
Table 1 Species of infected gastropods the deposited cox 1 and 165 GenBank accession numbers, area of collection, species of parasites, larval stage and number of larvae in each gastropod, and area of gastropods' collection

\begin{tabular}{|c|c|c|c|c|c|}
\hline $\begin{array}{l}\text { Gastropod species (GenBank } \\
\text { ID: cox1/16S) }\end{array}$ & Locality & Coordinates & Altitude (masl) & Parasite species & Life stage \\
\hline \multicolumn{6}{|l|}{ Snails } \\
\hline $\begin{array}{l}\text { Helix lucorum } \\
\text { (MT293861/MT298682) }\end{array}$ & Kozani & $40.28^{\prime} \mathrm{N}, 21.78^{\prime} \mathrm{E}$ & 710 & Aelurostrongylus abstrusus & $\mathrm{L} 3(n=4)$ \\
\hline $\begin{array}{l}\text { Massylaea vermiculata } \\
\text { (MT293859/MT298680) }\end{array}$ & Vyronia & $41.26^{\prime} \mathrm{N}, 23.25^{\prime} \mathrm{E}$ & 9 & Aelurostrongylus abstrusus & $\mathrm{L} 3(n=10)$ \\
\hline $\begin{array}{l}\text { Helix lucorum } \\
\text { (MT293862/-) }\end{array}$ & Lake Koronia & $40.70^{\prime} \mathrm{N}, 23.18^{\prime} \mathrm{E}$ & 100 & Angiostrongylus chabaudi & $\mathrm{L} 3(n=5)$ \\
\hline $\begin{array}{l}\text { Massylaea vermiculata } \\
\text { (MT293860/MT298681) }\end{array}$ & Lake Koronia & $40.70^{\prime} \mathrm{N}, 23.18^{\prime} \mathrm{E}$ & 100 & Angiostrongylus chabaudi & L3 $(n=58)$ \\
\hline \multicolumn{6}{|l|}{ Slugs } \\
\hline $\begin{array}{l}\text { Tandonia cf. sowerbyi } \\
\text { (MT293863/MT298683) }\end{array}$ & Lake Kerkini & $41.23^{\prime} \mathrm{N}, 23.09^{\prime} \mathrm{E}$ & 35 & Troglostrongylus brevior & $\operatorname{L} 2(n=1) ; \operatorname{L} 3(n=10)$ \\
\hline $\begin{array}{l}\text { Limax cf. conemenosi } \\
\text { (MT293864/MT298684) }\end{array}$ & Lake Volvi & $40.65^{\prime} \mathrm{N}, 23.49^{\prime} \mathrm{E}$ & 55 & Angiostrongylus chabaudi & $\mathrm{L} 1(n=5) ; \mathrm{L} 3(n=4)$ \\
\hline $\begin{array}{l}\text { Limax cf. conemenosi } \\
\text { (MT293865/MT298685) }\end{array}$ & Lake Volvi & $40.65^{\prime} \mathrm{N}, 23.49^{\prime} \mathrm{E}$ & 55 & Angiostrongylus chabaudi & $\mathrm{L} 3(n=2)$ \\
\hline
\end{tabular}

Abbreviations: masl, meters above sea level; L1, first-stage larvae; L2, second-stage larvae; L3, third-stage larvae

Tandonia cf. sowerbyi (Férussac, 1823) by its external morphology, but its DNA identification was feasible only at the genus level (Tandonia sp.), because the sequence clustered significantly within the Tandonia cluster in the NJ tree (not shown). Yet, there was no obvious match with any specific Tandonia reference sequence, since the closest best-match sequence similarities were only 88-94\% (three Tandonia species). Similarly, 2 slugs collected near Lake Volvi were identified as Limax cf. conemenosi Boettger, 1882 by their external morphology, but their DNA-based identification was feasible only at the genus level (Limax sp.), because of significant clustering within the Limax cluster in the NJ tree (not shown), but without a clear match with any specific Limax reference sequence, except for a $100 \%$ cox 1 sequence match with "Limax sp. Balkan". The available specimens were juveniles, thus morphological examination of the reproductive system that would allow identification at the species level was not possible. DNA-based species identifications were consistent between $\operatorname{cox} 1$ and $16 \mathrm{~S}$ in terms of best matching with reference sequences in GenBank and/or BOLD, supported branching NJ clustering NJtrees and the morphological corroboration. The obtained cox 1 and $16 S$ sequences of the identified gastropods have been deposited in the GenBank database under the accession numbers shown in Table 1.

Larvae of $A$. abstrusus were found in M. vermiculata ( $n$ $=10$, L3) from Vyronia and H. lucorum $(n=4$, L3) collected from Kozani. Troglostrongylus brevior $(n=1 \mathrm{~L} 2$ and $n=10 \mathrm{~L} 3)$ were found in $T$. cf. sowerbyi collected from Kerkini Lake. Angiostrongylus chabaudi were found in $L$. cf. conemenosi ( $n=5 \mathrm{~L} 1$ and $n=4 \mathrm{~L} 3$ ) collected from the area of Lake Volvi and in H. lucorum ( $n=5$ L3) and $M$. vermiculata ( $n=58 \mathrm{~L} 3)$, from Lake Koronia (Table 1$)$.

\section{Identification of metastrongyloid nematodes}

Aelurostrongylus abstrusus L3 (Fig. 2) were C-shaped, 444-608 $\mu \mathrm{m}$ in length with maximum body width of 25-33 $\mu \mathrm{m}$. The length of the oesophagus was 175-195 $\mu \mathrm{m}$ with the distance of the nerve-ring from the anterior extremity measuring $75-85 \mu \mathrm{m}$. The posterior end was conical with a rounded projection, the characteristic knob of $A$. abstrusus L3 (Fig. 3). The distance from the anus to the tip of the knob was 28-35 $\mu \mathrm{m}$. The genital primordium was observed at $162-193 \mu \mathrm{m}$ from the caudal extremity and the excretory pore was approximately at 91-94 $\mu \mathrm{m}$ from the cephalic extremity of the larvae (Table 2).

The second-stage larva (L2) of T. brevior (Fig. 4) found in $T$. cf. sowerbyi was C-shaped, covered with the cuticle of $\mathrm{L} 1$, measuring $330 \mu \mathrm{m}$ in length and $20 \mu \mathrm{m}$ in width. The oesophagus was $160 \mu \mathrm{m}$ and tail (anus to posterior extremity) was $35 \mu \mathrm{m}$ in length. The anterior extremity was narrow, widening progressively towards the middle of the body that showed granular content. Third-stage larvae (L3) (Fig. 2) were also C-shaped, measured 428$497 \mu \mathrm{m}$ in length, with maximum body width of $20-25$ $\mu \mathrm{m}$, observed at about mid-body. The oesophagus was 125-158 $\mu \mathrm{m}$ long, the nerve-ring was located at 75-80 $\mu \mathrm{m}$ from the anterior extremity and the anus to tail distance was 40-43 $\mu \mathrm{m}$. Genital primordium was situated at $167-178 \mu \mathrm{m}$ from the posterior extremity while the excretory pore was located slightly posterior to the 


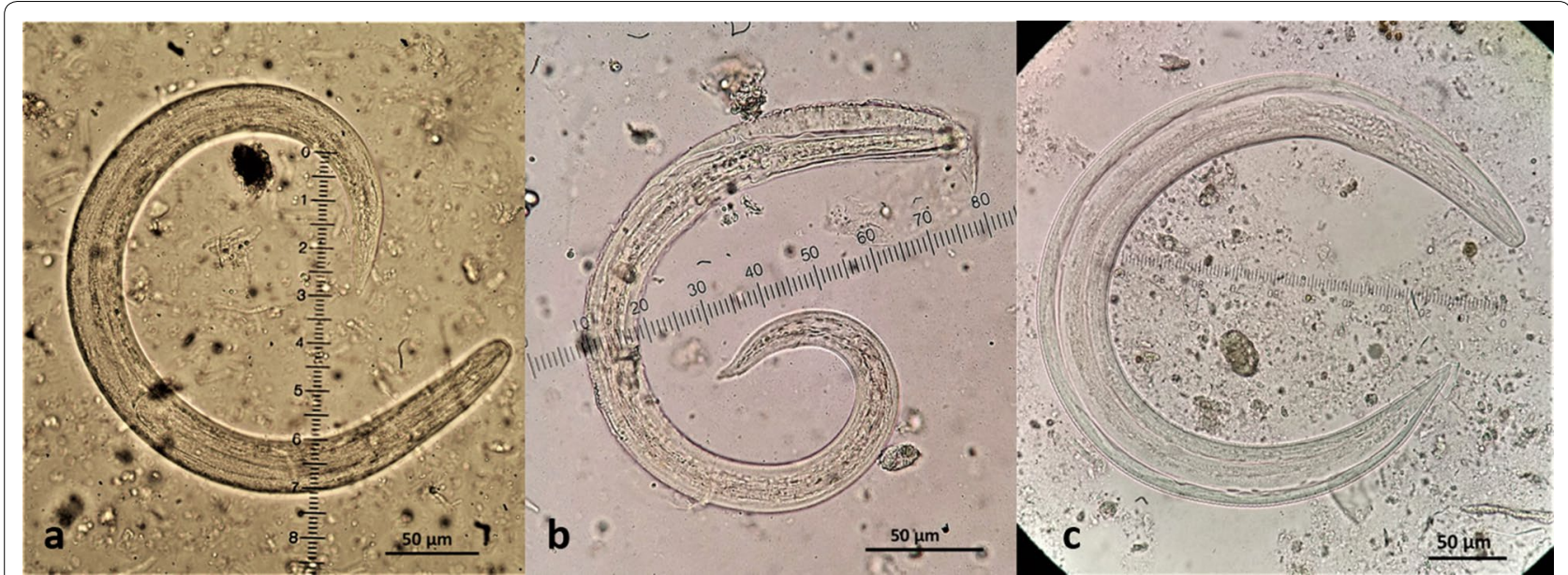

Fig. 2 Third-stage larvae (L3) of feline cardiopulmonary nematodes found in naturally infected intermediate gastropod hosts in Greece. a Aelurostrongylus abstrusus. b Troglostrongylus brevior. c Angiostrongylus chabaudi

nerve-ring, at $85-92 \mu \mathrm{m}$ from the anterior extremity (Table 2). The caudal region was slightly bent dorsally and ended in three terminal notches (one caudal and two ventral) and a small, slightly rounded appendage (Fig. 3).

Five $A$. chabaudi larvae found in $L$. cf. conemenosi were in the first stage (L1, Fig. 3), measuring 310-345 $\mu \mathrm{m}$ in length and $15-19 \mu \mathrm{m}$ in width. The anus was placed at 33-38 $\mu \mathrm{m}$ from the posterior extremity that showed the typical L1 kinked tail morphology with a subterminal dorsal spine separated by a moderately wide and distinct notch. The oesophagus measured $100-160 \mu \mathrm{m}$ in length and the nerve-ring was evident at $43-80 \mu \mathrm{m}$ from the anterior extremity. The excretory pore was situated slightly posterior to the nerve-ring at $75-88 \mu \mathrm{m}$ from the anterior extremity. The genital primordium was small and oval in shape situated at $100-113 \mu \mathrm{m}$ from the posterior extremity. The L3 of A. chabaudi (Fig. 2) were 444-868 $\mu \mathrm{m}$ in length and $32-40 \mu \mathrm{m}$ in width, with a transversally striated cuticle. The oesophagus was $175-250 \mu \mathrm{m}$ in length and the nerve-ring was located at 88-110 $\mu \mathrm{m}$ from the anterior extremity. The excretory pore was situated slightly posterior to the nerve-ring, at 93-112 $\mu \mathrm{m}$ from the anterior extremity. The genital primordium was located at 90-168 $\mu \mathrm{m}$ from the posterior extremity of the parasite (Table 2). The anus to tip of the body distance

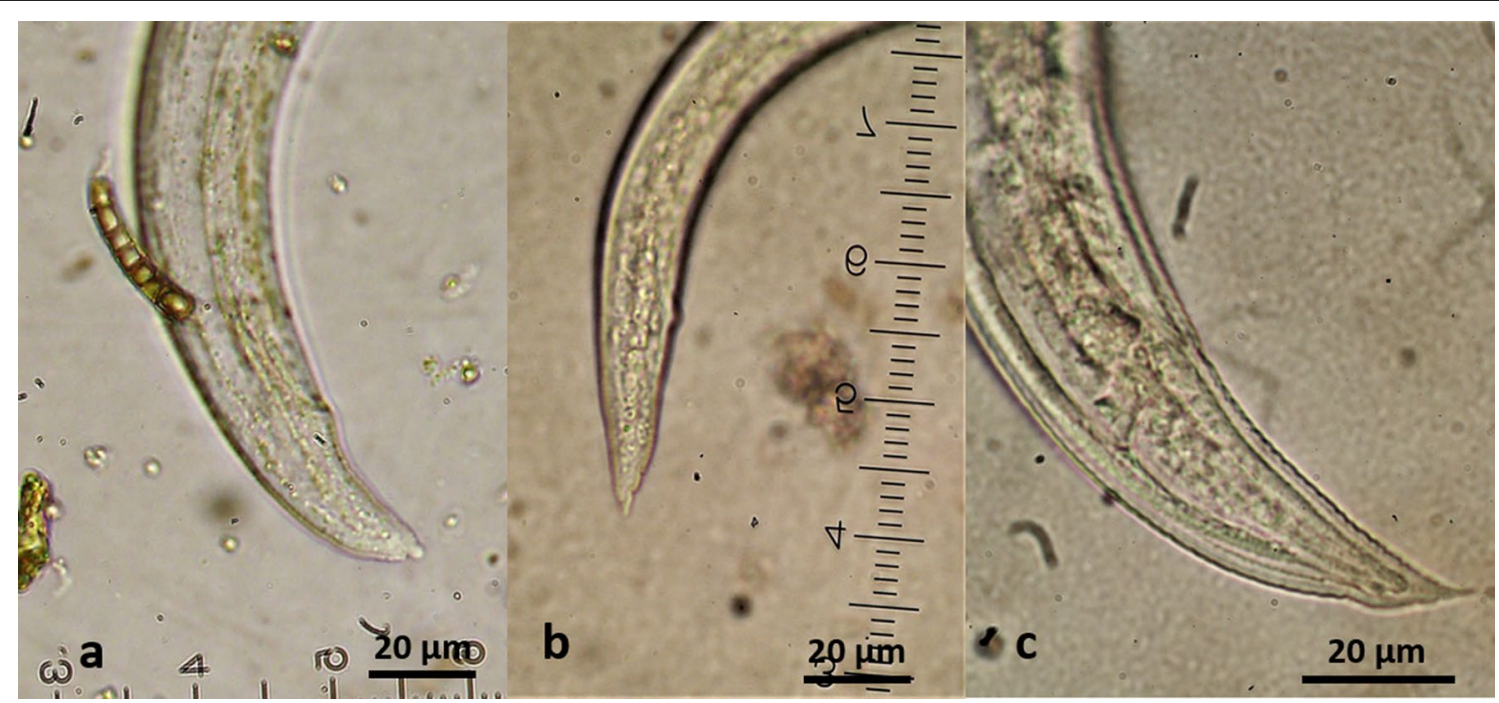

Fig. 3 Morphology of the posterior region of the third-stage larvae ( $L 3)$ of feline cardiopulmonary nematodes found in naturally infected intermediate gastropod hosts in Greece. a Aelurostrongylus abstrusus with a terminal knob. b Troglostrongylus brevior with one caudal and two ventral notches and a small slightly rounded tip of tail. c Angiostrongylus chabaudi with two caudal notches and an acute tip of tail 
Table 2 Measurements (in $\mu \mathrm{m}$ ) of the larval stages of feline cardiopulmonary nematodes in gastropods in Greece, presented with corresponding ranges from previous reports

\begin{tabular}{|c|c|c|c|c|c|c|c|c|c|c|c|}
\hline \multirow[t]{3}{*}{ Characteristics } & \multicolumn{3}{|c|}{ Aelurostrongylus abstrusus } & \multicolumn{6}{|c|}{ Troglostrongylus brevior } & \multicolumn{2}{|c|}{$\begin{array}{l}\text { Angiostrongylus } \\
\text { chabaudi }\end{array}$} \\
\hline & \multirow{2}{*}{$\begin{array}{l}E^{a} \\
\text { L3 }\end{array}$} & \multirow{2}{*}{$\begin{array}{l}\mathrm{N}^{\mathrm{b}} \\
\mathrm{L3}\end{array}$} & \multirow{2}{*}{$\begin{array}{l}\mathrm{P}(n=14) \\
\mathrm{L} 3\end{array}$} & \multicolumn{2}{|l|}{$\mathrm{E}^{\mathrm{C}}$} & \multicolumn{2}{|l|}{$N^{d}$} & \multicolumn{2}{|c|}{$\begin{array}{l}P(L 2=1, L 3 \\
=10)\end{array}$} & \multirow{2}{*}{$\begin{array}{l}E^{e} \\
\text { L3 }\end{array}$} & \multirow{2}{*}{$\begin{array}{l}\mathrm{P}(n=69) \\
\mathrm{L} 3\end{array}$} \\
\hline & & & & L2 & L3 & L2 & L3 & L2 & L3 & & \\
\hline Total body length & $459-670$ & $330-635$ & $444-608$ & $330-399$ & $417-450$ & $\mathrm{nr}$ & $\mathrm{nr}$ & 330 & $428-497$ & $580-710$ & $444-868$ \\
\hline Maximum body width & $25-38$ & $22-38$ & $25-33$ & $22-28$ & $19-23$ & $\mathrm{nr}$ & $\mathrm{nr}$ & 20 & $20-25$ & $28-43$ & $32-40$ \\
\hline Oesophagus length & $194-221$ & $130-215$ & $175-195$ & $110-125$ & $121-145$ & $\mathrm{nr}$ & $\mathrm{nr}$ & 160 & $125-158$ & $213-277$ & $175-250$ \\
\hline Nerve-ring to anterior extremity & $75-80$ & $40-72$ & $75-85$ & $\mathrm{nv}$ & $60-67$ & $\mathrm{nr}$ & $\mathrm{nr}$ & $\mathrm{nv}$ & $75-80$ & $76-102$ & $88-110$ \\
\hline Anus to posterior extremity & $34-44$ & $20-35$ & $28-35$ & 35 & $30-42$ & $\mathrm{nr}$ & $\mathrm{nr}$ & 35 & $40-43$ & $27-47$ & $43-55$ \\
\hline Primordium to posterior extremity & $126-265$ & $150-180$ & $162-193$ & nv & 168 & $\mathrm{nr}$ & $\mathrm{nr}$ & nv & $167-178$ & $181-222$ & $90-168$ \\
\hline Excretory pore to anterior extremity & $87-102$ & $90-99$ & $91-94$ & nv & $50-79$ & $\mathrm{nr}$ & $\mathrm{nr}$ & nv & $85-92$ & 84-119 & $93-112$ \\
\hline \multicolumn{12}{|l|}{ a References [10, 28, 29, 32, 34, 46-48] } \\
\hline \multicolumn{12}{|l|}{ b References $[31,35,36]$} \\
\hline \multicolumn{12}{|l|}{ ' References $[10,28]$} \\
\hline \multicolumn{12}{|l|}{${ }^{d}$ References $[38,39]$} \\
\hline \multicolumn{12}{|l|}{ e Reference [44] } \\
\hline
\end{tabular}

was $43-55 \mu \mathrm{m}$. The posterior end showed a quite sharp final tip, and two caudal notches (Fig. 3).

Table 2 provides the measurements of all developmental stages of the nematode species reported here in comparison with previously reported data $[10,28,29,31,32$, 34-36, 38, 39, 46, 48-50].

The identity of the larvae microscopically identified as A. abstrusus, T. brevior and A. chabaudi was molecularly confirmed by the species-specific PCRs and sequencing. Specifically, the ITS2 regions of $A$. abstrusus, $T$. brevior and $A$. chabaudi here generated displayed $100 \%$ homology with sequences available on GenBank (GenBank: DQ372965.2, KM506759.1 and KM216825.1, respectively).

\section{Discussion}

The results of the present study have been preliminarily presented at the International Congress on the Zoogeography and Ecology of Greece and Adjacent Regions in June 2019 [51]. Subsequently, the presence of T. brevior in terrestrial gastropods in Europe was confirmed in Austria, though from a different intermediate slug host [39]. The findings on $A$. chabaudi, including the description of its larval stages are relevant, because the life-cycle of A. chabaudi is still poorly known, and the present study confirms for the first time that gastropods are competent intermediate hosts in natural conditions.

Gastropods act as intermediate hosts for various parasites [27, 52], including feline cardiopulmonary nematodes. These nematodes have been successfully developed in snails or slugs in a series of experimental infections (Table 2). However, experimental infection and observation of parasite development in tissues of gastropods do not necessarily indicate that the specific gastropod species can act as a natural intermediate host or have any epizootiological importance. Thus, the current knowledge on gastropod species involved in the transmission of feline metastrongyloid parasites in natural conditions is limited. Nevertheless, natural infections with $A$. abstrusus have been occasionally reported (Table 2). In the case of T. brevior there are recent reports of natural infection in Lissachatina fulica and Arion vulgaris in Colombia and Austria, respectively [38, 39], although no morphological description of the isolated parasites is provided. Hence, the present results add new gastropod species to the natural intermediate host spectrum of the three nematodes.

As expected, the circulation of gastropod transmitted nematodes depends on the (micro-) distributional dynamics of their intermediate hosts $[29,53]$. In some cases, this may explain the patchy distribution of snailborne nematodes, such as Angiostrongylus vasorum [54]. In this context, it is important to assess and understand some basic biological characteristics of the gastropods in question. Helix lucorum and M. vermiculata, which were here found to harbour both $A$. abstrusus and $A$. chabaudi, are widespread over southern Europe and have been introduced in several regions within and beyond 


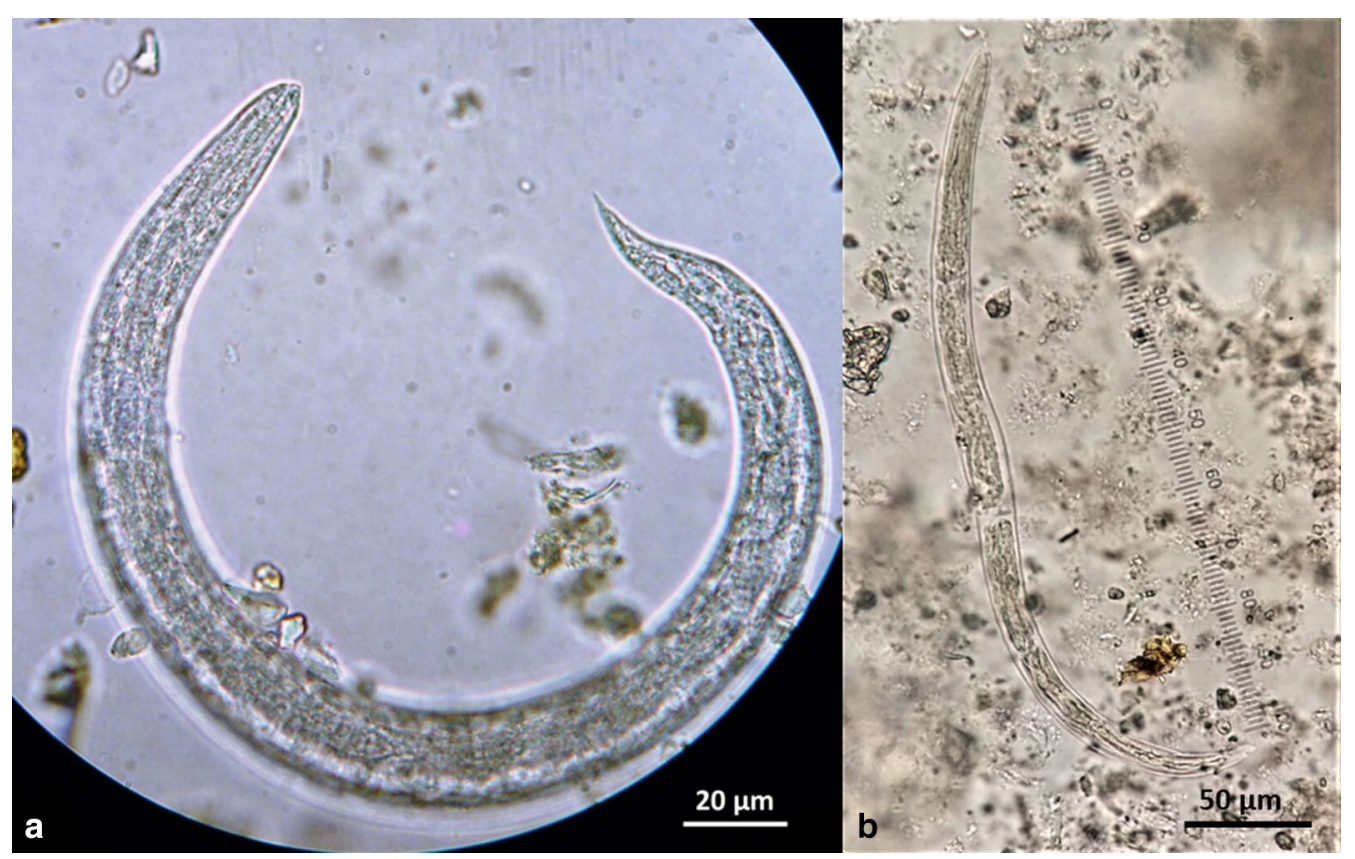

Fig. 4 Troglostrongylus brevior (L2) (a) and Angiostrongylus chabaudi (L1) (b) found in naturally infected gastropods in Greece

their native area, where they may be found in natural and anthropized habitats [55-57]. As these snails are synanthropic species, are being cultured (heliciculture), consumed and traded [58], they may be easily and repetitively transferred, potentially contributing to the spreading and establishment of metastrongyloids in new areas. Subsequently, all regions where $M$. vermiculata (Europe, Asia, Africa, USA and Australia) and H. lucorum (southern Europe and the south and west of the Caspian Sea) have been recorded may be at risk of $A$. abstrusus and A. chabaudi infections in felids. While to date A. abstrusus has been reported from many parts of the world, i.e. Europe, Kenya [59], Australia [60], South America [32, 61, 62], Israel [63] and the USA [64], A. chabaudi has only been reported from Bulgaria, Bosnia and Herzegovina, Germany, Greece, Italy, Romania and Spain $[2,5,6$, $18-20,65]$. However, the dispersal capacity of the intermediate hosts reported here (two of which are commonly introduced elsewhere in Europe), makes it plausible that A. chabaudi may expand beyond its current distribution in Europe.

Both $H$. lucorum and $M$. vermiculata have a life span of at least two to five years, but $H$. lucorum may become much older (up to $>14$ years) [66-69]. Thus, these snails may accumulate and maintain the nematode infective L3 stage for long periods, as for example, A. abstrusus L3 can survive for up to two years in infected gastropods [70]. According to the authors' experience $A$. chabaudi $\mathrm{L} 3$ remain alive in gastropods preserved at $-20^{\circ} \mathrm{C}$ for at least two years (unpublished data), thus low temperatures during the hibernation period of the snails most probably do not affect the vitality of the larvae. Thus, snails may maintain and conserve the infective stage of the parasites from one activity season, throughout hibernation, to the next one. Interestingly, it has been recently shown under experimental conditions that natural hibernation of snails may enhance the parasitic burden, at least for T. brevior infective larvae [71]. It would be interesting to document for how long L3 can remain alive and infective inside the gastropods in natural conditions, as this would provide information about the potential of the parasites to accumulate in the gastropod population of a given environment. Depending on the gastropod species and the environmental temperature, it takes around two to three weeks for A. abstrusus L1 to develop to L3 [10, 28, 29] and 10-30 days for A. chabaudi L1 to develop to L3 [46]. Given this variation in developmental times and considering that the development of larvae depends on the age and size of the gastropods [28, 29, 36, 49], it is not surprising that some larval measurements reported here differ significantly from those published elsewhere (Table 2).

The slugs $T$. cf. sowerbyi and $L$. cf. conemenosi, which were infected with $T$. brevior and A. chabaudi, respectively, are neither consumed by man nor cultured, but have a synanthropic biology. As such they are easily transported by man (e.g. via objects, media of transportation, goods) and introduced in areas beyond their native 
ranges [72, 73]. Tandonia sowerbyi is a eurytopic species that lives in a wide variety of habitats where it hides under shrubs, stones, wood and soil litter. It prefers areas free of tree cover, but it can also be abundant in wastelands, gardens and farm-lands [72-74], i.e. environments that meet the characteristics of the wildcat-domestic cat sympatric habitats. It is native and very common in Greece and has been introduced in various areas of the world [72, 75]. Although more gastropod species likely act as intermediate host of T. brevior, the distribution of T. sowerbyi in southern-eastern Europe, and South America overlaps that of felid T. brevior infections hitherto reported $[13,15,22]$. Apart from the suitable gastropod species, the development of T. brevior L1 to L3 depends on the environmental temperature, varying accordingly from eight to 40 days, thus even the smallest temperature change could alter the distribution of gastropod borne diseases [76-79]. Consequently, global warming may facilitate the expansion of cardiopulmonary nematodes in more northern geographical areas, both by permitting the establishment of suitable gastropod species in these areas where they are currently absent $[36,76]$ and by shortening the period of extrinsic parasite development. The range of $L$. conemenosi that is native to Greece extends to Bulgaria, Republic of North Macedonia and Albania [73, 74, 80, 81]. This species lives mainly in rural areas $[73,74,80]$, yet in the present study it was found in a wild habitat close to Lake Volvi. The occurrence of this species in natural and anthropized environments may facilitate the spread of metastrongyloid nematodes from wildcats to domestic cats and vice versa.

Among the localities where wildcats and domestic cats occur in sympatry in the present study, the wetland areas of lakes Kerkini, Koronia and Volvi (Fig. 1) are listed in Natura 2000 [82] a geographical network of protected areas where rare and threatened wildlife species can breed and rest. The areas around these lakes are typical wildcat habitats with a well-established population of wildcats $[83,84]$. In the same areas there are villages, where domestic cats either free roam or have outdoor access. Similarly, in more urbanised environments such as the areas near the city of Kozani and the village of Vyronia (Fig. 1), wildcats searching for food may approach areas close to human activity, where free roaming domestic cats are present. Under the conditions in all five areas of the present study, wildcats and domestic cats live in sympatry $[85,86]$, thus creating the conditions for the spread of parasites harboured by one group of animals to the other [6,21, 87]. A spillover of this kind has been demonstrated for $A$. vasorum, as in areas where foxes (the natural host reservoir) are heavily parasitized, wolves and dogs are also infected [9, 88-93]. As infections with $A$. abstrusus, $T$. brevior and $A$. chabaudi were recently reported in $F$. silvestris in areas close to human activity [21,94], the epizootiological pressure to domestic cats is a realistic scenario.

Reports of domestic cats co-infected with A. abstrusus, T. brevior and $A$. chabaudi $[6,12,13]$ support the existence of a shared transmission pattern for these nematodes among their definitive (domestic cats and wildcats) and intermediate hosts. In wildcat habitats these parasites circulate in the sylvatic life-cycle among wildcats, intermediate and paratenic hosts [87] (AD, unpublished data), rendering these areas a possible source of infection for domestic cats that live in proximity.

The present data were obtained from a limited number of specimens and do not permit solid conclusions about the prevalence of infection of gastropods by feline cardiopulmonary nematodes and the corresponding pressure of parasite spillover in areas of wildcat and domestic cat sympatry. Yet, for $A$. chabaudi, it has been recently suggested that domestic cats are, for the time being, not in particular risk [95]. However, the data presented herein are of importance under biological and epizootiological standpoints. Information about the suitability of various intermediate hosts and knowledge about their distribution, biological features and abundance is important in order to predict the expansion of cardiopulmonary parasites in felids and the possible risk of parasite spillover. Finally, the prevalence of infection of gastropods that act as intermediate hosts of feline metastrongyloids in the areas of study remains to be assessed and would provide additional important information on the epizootiology of these parasites.

\section{Conclusions}

To the best of our knowledge, the present study offers for the first time conclusive evidence that gastropods act as intermediate hosts for $A$. chabaudi under natural conditions. Furthermore, developmental stages of T. brevior are reported and morphologically described for the first time in gastropods in Europe and infected intermediate gastropod hosts of $A$. abstrusus were for the first time detected in Greece. The biological characteristics and distribution patterns of these gastropods suggest that these three parasites may further expand to areas where infected felids have not yet been reported. Finally, this study suggests that these parasitic nematodes may crossinfect wildcats and domestic cats in areas were these animals live in sympatry.

\section{Abbreviations}

BOLD: barcode of life data; BLASTn: nucleotide basic local alignment search tool; cox1: cytochrome coxidase subunit 1; dNTP: deoxynucleoside triphosphates; IDS: identification system; L1: first-stage larva; L2: second-stage larva; L3: third-stage larva; mtDNA: mitochondrial DNA; NJ: neighbor-joining; UV: ultraviolet. 


\section{Acknowledgements}

This study was supported by BopCo (http://bopco.myspecies.info/), which is a contribution of the Belgian Science Policy Office (BELSPO) to the European Research Infrastructure Consortium LifeWatch (https://www.lifewatch.eu/ web/guest/home)

\section{Authors' contributions}

DD contributed to the design of the study, collected the gastropods, performed the parasitological examinations and prepared the first draft of the paper. SM, DT and ADC performed the DNA-based identification of the parasites. YRVB, KB and TB performed the morphology and DNA-based identification of gastropods. AFR performed the sequencing of the parasites' PCR amplicons. AD conceived and designed the study, contributed to the collection and parasitological examination of the gastropods and provided the overall supervision of the study. All authors contributed to the final version of the manuscript. DT, TB and AD critically reviewed the final version of the manuscript. All authors read and approved the final manuscript.

\section{Funding}

Not applicable.

\section{Availability of data and materials}

All data generated or analysed during this study are included in this published article. Representative sequences were deposited in the GenBank database under the accession numbers MT293861, MT298682, MT293862 (Helix lucorum), MT293859, MT298680, MT293860, MT298681 (Massylaea vermiculata), MT293863, MT298683 (Tandonia cf. sowerbyi), MT293864, MT298684, MT293865, MT298685 (Limax cf. conemenosi). Any additional data (photographs etc.) are available upon request.

\section{Ethics approval and consent to participate}

Not applicable. Gastropods (snails and slugs) are not included in the National and European Regulation about the use and welfare of animals, thus approval of the research from an Ethical Committee was not required for the present study.

\section{Consent for publication}

Not applicable.

\section{Competing interests}

The authors declare that they have no competing interests.

\section{Author details}

${ }^{1}$ School of Veterinary Medicine, Faculty of Health Sciences, Aristotle University of Thessaloniki, 54124 Thessaloniki, Greece. ${ }^{2}$ Faculty of Veterinary Medicine, Teaching Veterinary Hospital, 64100 Teramo, Italy. ${ }^{3}$ Royal Belgian Institute of Natural Sciences (BopCo - LifeWatch Belgium), 1000 Brussels, Belgium. ${ }^{4}$ Evolutionary Ecology Group, Department of Biology, University of Antwerp, 2610 Antwerp, Belgium. ${ }^{5}$ Department of Animal Medicine, Production and Health, University of Padua, 35020 Padua, Italy.

Received: 1 April 2020 Accepted: 2 July 2020

Published online: 10 July 2020

\section{References}

1. Traversa D, Di Cesare A. Feline lungworms: what a dilemma. Trends Parasitol. 2013;29:423-30.

2. Giannelli A, Kirkova Z, Abramo F, Latrofa MS, Campbell B, Zizzo N, et al. Angiostrongylus chabaudi in felids: new findings and a review of the literature. Vet Parasitol. 2016;228:188-92.

3. Brianti E, Gaglio G, Giannetto S, Annoscia G, Latrofa MS, Dantas-Torres F, et al. Troglostrongylus brevior and Troglostrongylus subcrenatus (Strongylida: (renosomatidae) as agents of broncho-pulmonary infestation in domestic cats. Parasit Vectors. 2012;5:178.

4. Brianti E, Giannetto S, Dantas-Torres F, Otranto D. Lungworms of the genus Troglostrongy/us (Strongylida: Crenosomatidae): neglected parasites for domestic cats. Vet Parasitol. 2014;202:104-12.
5. Varcasia A, Tamponi C, Brianti E, Cabras PA, Boi R, Pipia AP, et al. Angiostrongylus chabaudi Biocca, 1957: a new parasite for domestic cats? Parasit Vectors. 2014;7:588

6. Traversa D, Lepri E, Veronesi F, Paoletti B, Simonato G, Diaferia M, et al. Metastrongyloid infection by Aelurostrongylus abstrusus, Troglostrongylus brevior and Angiostrongylus chabaudi in a domestic cat. Int J Parasitol. 2015;45:685-90.

7. Crisi PE, Di Cesare A, Boari A. Feline troglostrongylosis: current epizootiology, clinical features, and therapeutic options. Front Vet Sci. 2018:5:126.

8. Traversa D, Salda LD, Diakou A, Sforzato C, Romanucci M, di Regalbono $A F$, et al. Fatal patent troglostrongylosis in a litter of kittens. Parasitology. 2018;104:418-23.

9. Traversa D, Di Cesare A, Conboy G. Canine and feline cardiopulmonary parasitic nematodes in Europe: emerging and underestimated. Parasit Vectors. 2010;3:62.

10. Gerichter CB. Studies on the nematodes parasitic in the lungs of Felidae in Palestine. Parasitology. 1949;39:251-62.

11. Paggi L. Segnalazione in Italia centrale di Troglostrongylus spp. parassita dei polmoni dei felidi. Parassitologia. 1959;1:80-1.

12. Di Cesare A, Veronesi F, Grillotti E, Manzocchi S, Perrucci S, Beraldo P et al. Respiratory nematodes in cat populations of Italy. Parasitol Res. 2015;114:4463-9.

13. Diakou A, Di Cesare A, Barros LA, Morelli S, Halos L, Beugnet F, et al. Occurrence of Aelurostrongylus abstrusus and Troglostrongylus brevior in domestic cats in Greece. Parasit Vectors. 2015;8:590.

14. Alic A, Traversa D, Duscher GG, Kadric M, Di Cesare A, Hodzic A. Troglostrongylus brevior in an Eurasian lynx (Lynx lynx) from Bosnia and Herzegovina. Parasit Vectors. 2015;8:653.

15. Giannelli A, Capelli G, Joachim A, Hinney B, Losson B, Kirkova Z, et al. Lungworms and gastrointestinal parasites of domestic cats: a European perspective. Int J Parasitol. 2017:47:517-28.

16. Györke A, Dumitrache MO, Kalmar Z, Pastiu Al, Mircean V. Molecular survey of metastrongyloid lungworms in domestic cats (Felis silvestris catus) from Romania: a retrospective study (2008-2011). Pathogens. 2020;9:80.

17. Biocca E. Angiostrongylus chabaudi n. sp. parassita del cuore e dei vasi polmonari del gatto selvatico (Felis silvestris). R Accad Naz Lincei. 1957;22:526-32.

18. Diakou A, Psalla D, Migli D, Di Cesare A, Youlatos D, Marcer F, et al. First evidence of the European wildcat (Felis silvestris silvestris) as definitive host of Angiostrongylus chabaudi. Parasitol Res. 2016;115:1235-44.

19. Gherman CM, lonică AM, D'Amico G, Otranto D, Mihalca AD. Angiostrongylus chabaudi (Biocca, 1957) in wildcat (Felis silvestris silvestris, S) from Romania. Parasitol Res. 2016;115:2511-7.

20. Stevanovic O, Diakou A, Morelli S, Paras S, Trbojevic I, Nedic D, et al. Severe verminous pneumonia caused by natural mixed infection with Aelurostrongylus abstrusus and Angiostrongylus chabaudi in a European wildcat from Western Balkan area. Acta Parasitol. 2019:64:411-7.

21. Veronesi F, Traversa D, Lepri E, Morganti G, Vercillo F, Grelli D, et al. Occurence of lungworms in European wildcats (Felis silvestris silvestris) of Central Italy. J Wild Dis. 2016;52:270-8.

22. Di Cesare A, Di Francesco G, Frangipane di Regalbono A, Eleni C, De Liberato $C$, et al. Retrospective study on the occurrence of the feline lungworms Aelurostrongylus abstrusus and Troglostrongylus spp. in endemic areas of Italy. Vet J. 2015;203:233-8.

23. Traversa D, Veronesi F, Diakou A, lorio R, Simonato G, Marcer F, et al. Mitochondrial haplotypes of Aelurostrongylus abstrusus and Troglostrongylus brevior (Nematoda, Metastrongyloidea) from domestic and wild felids. Parasitol Res. 2017:116:1227-35.

24. Diakou A, Di Cesare A, Aeriniotaki T, Traversa D. First report of Troglostrongylus brevior in a kitten in Greece. Parasitol Res. 2014;113:3895-8.

25. Traversa D, Di Cesare A. Cardio-pulmonary parasitic nematodes affecting cats in Europe: unraveling the past, depicting the present, and predicting the future. Front Vet Sci. 2014;1:11

26. Traversa D, Di Cesare A. Diagnosis and management of lungworm infections in cats: cornerstones, dilemmas and new avenues. J Fel Med Surg. 2016:18:7-20.

27. Grewal PS, Grewal SK, Tan L, Adams BJ. Parasitism of molluscs by nematodes: types of associations and evolutionary trends. J Nematol. 2003;35:146-56.

28. Giannelli A, Ramos RA, Annoscia G, Di Cesare A, Colella V, Brianti $\mathrm{E}$, et al. Development of the feline lungworms Aelurostrongylus 
abstrusus and Troglostrongylus brevior in Helix aspersa snails. Parasitology. 2014;141:563-9.

29. Di Cesare A, Crisi PE, Di Giulio E, Veronesi F, di Regalbono AF, Talone T, et al. Larval development of the feline lungworm Aelurostrongylus abstrusus in Helix aspersa. Parasitol Res. 2013;112:3101-8.

30. Cardillo NM, Ercole M, Farina F, Pasqualetti M, Loiza Y, Perez M, et al. Larval development of Aelurostrongylus abstrusus in experimentally infected Rumina decollata snails. Vet Parasitol. 2018;251:50-5.

31. Andrade-Porto SM, Souza KCP, Cárdenas MQ, Roque RA, Pimpão DM, Araújo CS, et al. Occurrence of Aelurostrongylus abstrusus (Railliet, 1898) larvae (Nematoda: Metastrongylidae) infecting Achatina (Lissachatina) fulica Bowdich, 1822 (Mollusca: Gastropoda) in the Amazon region. Acta Amaz. 2012;42:245-50.

32. Thiengo SC, Fernandez MA, Torres EJL, Coelho PM, Lanfredi RM. First record of a nematode Metastrongyloidea (Aelurostrongylus abstrusus larvae) in Achatina (Lissachatina) fulica (Mollusca, Achatinidae) in Brazil. J Invertebr Pathol. 2008;98:34-9.

33. Ohlweiler FP, Guimarães MCdA, Takahashi FY, Eduardo JM. Current distribution of Achatina fulica, in the State of São Paulo including records of Aelurostrongylus abstrusus (Nematoda) larvae infestation. Rev Inst Med Trop SP. 2010;52:211-4.

34. Jezewski W, Bunkowska-Gawlik K, Hildebrand J, Perec-Matysiak A, Laskowski Z. Intermediate and paratenic hosts in the life cycle of Aelurostrongylus abstrusus in natural environment. Vet Parasitol. 2013;198:401-5.

35. Cardillo N, Clemente A, Pasqualetti M, Borrás P, Rosa A, Ribicich M. First report of Aelurostrongylus abstrusus in domestic land snail Rumina decollata, in the autonomous city of Buenos Aires. InVet. 2014;16:15-22.

36. Valente R, Diaz Jl, Salomon OD, Navone GT. Natural infection of the feline lungworm Aelurostrongylus abstrusus in the invasive snail Achatina fulica from Argentina. Vet Parasitol. 2017;235:17-9.

37. Lange MK, Penagos-Tabares F, Hirzmann J, Failing K, Schaper R, Van Bourgonie YR, et al. Prevalence of Angiostrongylus vasorum, Aelurostrongylus abstrusus and Crenosoma vulpis larvae in native slug populations in Germany. Vet Parasitol. 2018;254:120-30.

38. Penagos-Tabares F, Lange MK, Velez J, Hirzmann J, Gutierrez-Arboleda $J$, Taubert A, et al. The invasive giant African snail Lissachatina fulica as natural intermediate host of Aelurostrongylus abstrusus, Angiostrongylus vasorum, Troglostrongylus brevior, and Crenosoma vulpis in Colombia. PLoS Negl Trop Dis. 2019;13:e0007277.

39. Penagos-Tabares F, Gross KM, Hirzmann J, Hoos C, Lange MK, Taubert A, et al. Occurrence of canine and feline lungworms in Arion vulgaris in a park of Vienna: first report of autochthonous Angiostrongylus vasorum, Aelurostrongylus abstrusus and Troglostrongylus brevior in Austria. Parasitol Res. 2020;119:327-31.

40. Hellenic National Meteorological Service. Climatology. http://www.hnms. $\mathrm{gr} / \mathrm{emy} / \mathrm{el} / \mathrm{climatology} /$ climatology. Accessed 21 May 2020.

41. MolluscaBase. http://www.molluscabase.org. Accessed 20 Feb 2020.

42. Folmer O, Black M, Hoeh W, Lutz R, Vrijenhoek R. DNA primers for amplification of mitochondrial cytochrome $c$ oxidase subunit I from diverse metazoan invertebrates. Mol Mar Biol Biotechnol. 1994;3:294-9.

43. Palumbi SR. Nucleic acids II: the polymerase chain reaction. In: Hillis DM Moritz C, Mable BK, editors. Molecular systematics. Sunderland: Sinauer \& Associates Inc; 1996. p. 205-47.

44. Rowson B, Anderson R, Turner JA, Symondson WO. The slugs of Britain and Ireland: undetected and undescribed species increase a wellstudied, economically important fauna by more than 20\%. PLOS ONE. 2014;9:e91907.

45. Mayer-Scholl A, Pozio E, Gayda J, Thaben N, Bahn P, Nockler K. Magnetic stirrer method for the detection of Trichinella larvae in muscle samples. Vis Exp. 2017;121:e55354.

46. Colella V, Cavalera MA, Deak G, Tarallo VD, Gherman CM, Mihalca AD, et al. Larval development of Angiostrongylus chabaudi, the causative agent of feline angiostrongylosis, in the snail Cornu aspersum. Parasitology. 2017:144:1922-30.

47. Di Cesare A, Veronesi F, Frangipane di Regalbono A, lorio R, Traversa D. Novel molecular assay for simultaneous identification of neglected lungworms and heartworms affecting cats. J Clin Microbiol. 2015;53:3009-13.

48. Ash LR. Diagnostic morphology of the third-stage larvae of Angiostrongylus cantonensis, Angiostrongylus vasorum, Aelurostrongylus abstrusus, and Anafilaroides rostratus (Nematoda: Metastrongyloidea). J Parasitol. 1970:2:249-53.
49. Lopez C Panadero R Paz A, Sanchez-Andrade R Diaz P. Diez-Banos P et al. Larval development of Aelurostrongylus abstrusus (Nematoda, Angiostrongylidae) in experimentally infected Cernuella (Cernuella) virgata (Mollusca, Helicidae). Parasitol Res. 2005;95:13-6.

50. Zottler EM, Schnyder M. Larval development of the cat lungworm Aelurostrongylus abstrusus in the tropical freshwater snail Biomphalaria glabrata. Parasitol Open. 2016;2:e8.

51. Dimzas D, Diakou A, Di Cesare A, Van Bourgonie YR, Backeljau T, Traversa D. Gastropods as intermediate hosts of feline cardio-pulmonary parasites in Greece: preliminary results. In: 14th International Congress on the Zoogeography and Ecology of Greece and Adjacent Regions (ICZEGAR), 27-30 June 2019, Thessaloniki, Greece; 2019.

52. Anderson RC. Nematode parasites of vertebrates. Their development and transmission. 2nd ed. Wallingford: CABI Publishing; 2000

53. Jenkins EJ, Kutz SJ, Hoberg EP, Polley L. Bionomics of larvae of Parelaphostrongylus odocoilei (Nematoda: Protostrongylidae) in experimentally infected gastropod intermediate hosts. J Parasitol. 2006;92:298-305.

54. Morgan ER, Jefferies R, Krajewski M, Ward P, Shaw SE. Canine pulmonary angiostrongylosis: the influence of climate on parasite distribution. Parasitol Int. 2009:58:406-10.

55. Fechter R, Falkner G. Steinbachs Naturführer. München: Mosaik Verlag; 1990. p. 287.

56. Kerney MP, Cameron RAD, Bertrand A. Guide des escargots et limaces d'Europe: identification et biologie de plus de 300 espèces. Paris: Delachaux et Niestlé; 1999.

57. Cadevall J, Orozco A. Caracoles y babosas de la Península Ibérica y Baleares. Barcelona: Omega; 2016.

58. Conte R. Heliciculture: purpose and economic perspectives in the European community. IST Journal. 2015. https://www.researchgate.net/publi cation/275030005_Heliciculture_purpose_and_economic_perspectiv es in the European community.

59. Gathumbi P, Waruiru R, Buoro I. A case of feline Aelurostrongylus abstrusus infection in Kenya. Bull Anim Health Prod Afr. 1991;39:361-3.

60. Barrs VR, Swinney GR, Martin P, Nicoll RG. Concurrent Aelurostrongylus abstrusus infection and salmonellosis in a kitten. Aust Vet J. 1999:77:229-32.

61. Ferreira AMR, de Souza-Dantas LM, Labarthe N. A case of feline Aelurostrongylus abstrusus (Railliet, 1898) infection in Rio de Janeiro, RJ. Braz J Vet Res Anim Sci. 2007:44:24-6.

62. Penagos-Tabares F, Lange MK, Chaparro-Gutierrez JJ, Taubert A, Hermosilla C. Angiostrongylus vasorum and Aelurostrongylus abstrusus: neglected and underestimated parasites in South America. Parasit Vectors. 2018;11:208

63. Yasur-Landau D, Rojas A, Zehavi T, Yafe Y, Anug Y, Baneth G. First molecular identification of Aelurostrongylus abstrusus in a cat presenting severe respiratory disease from Israel. Vet Parasitol RSR. 2019;17:100304.

64. Hoggard KR, Jarriel DM, Bevelock TJ, Verocai GG. Prevalence survey of gastrointestinal and respiratory parasites of shelter cats in northeastern Georgia, USA. Vet Parasitol RSR. 2019;16:100270.

65. Steeb S, Hirzmann J, Eskens U, Volmer K, Bauer C. Lungenwurm-Infektionen bei der Europäischen Wildkatze. Kompakt Vet. 2014;3:9.

66. Staikou A, Lazaridou-Dimitriadou M, Farmakis N. Aspects of the life cycle, population dynamics, growth and secondary production of the edible snail Helix lucorum Linnaeus, 1758 (Gastropoda, Pulmonata) in Greece. J Moll Stud. 1988;54:139-55.

67. Heller J. Longevity in molluscs. Malacologia. 1990;31:259-95.

68. Lazaridou-Dimitriadou M, Kattoulas ME. Energy flux in a natural population of the land snail Eobania vermiculata (Müller) (Gastropoda: Pulmonata: Stylommatophora) in Greece. Can J Zool. 1991;69:881-91.

69. Topley P. Helix lucorum in captivity: Iongevity and calcification. Mollusc World. 2017:43:10-1.

70. Hamilton J. On the migration, distribution, longevity and pathogenicity of larvae of Aelurostrongylus abstrusus in the snail Helix aspersa. J Helminthol. 1969:43:319-25.

71. Morelli S, Traversa D, Colombo M, Raue K, Strube C, Pollmeier M, et al. The effect of the hibernation on the larval development of Troglostrongy/us brevior in the land snail Cornu aspersum. Vet Parasitol. 2020;282:109123.

72. Wiktor A. Milacidae (Gastropoda, Pulmonata) - systematic monograph. Ann Zool. 1987:41:3. 
73. Welter-Schultes FW. European non-marine molluscs, a guide for species identification. Bestimmungsbuch für europäische Land- und Süsswassermollusken. Göttingen: Planet Poster Editions; 2012.

74. Wiktor A. The slugs of Greece (Arionidae, Milacidae, Limacidae, Agriolimacidae-Gastropoda, Stylommatophora). Heraklion: Natural History Museum of Crete, Hellenic Zoological Society; 2001.

75. Barker G. The introduced slugs of New Zealand (Gastropoda: Pulmonata). New Zeal J Zool. 1979;6:411-37.

76. Strzelec M, Krodkiewska M, Królczyk A. The impact of environmental factors on the diversity of gastropod communities in sinkhole ponds in a coal mining region (Silesian Upland, southern Poland). Biologia. 2014:69:780-9.

77. Koprivnikar J, Baker RL, Forbes MR. Environmental factors influencing community composition of gastropods and their trematode parasites in southern Ontario. J Parasitol. 2007;93:992-9.

78. Ikpeze O, Obikwelu M. Factors affecting seasonal abundance of gastropods of public health importance found at Agulu Lake shorelines in Nigeria. Int J Pure Appl Biosci. 2016;4:91-102.

79. Rogers D, Randolph S. Climate change and vector-borne diseases. Adv Parasit. 2006:62:345-81

80. Wiktor A. The slugs of the former Yugoslavia (Gastropoda terrestria nuda - Arionidae, Milacidae, Limacidae, Agriolimacidae). Ann Zool. 1996:46:1-110.

81. Fehér Z, Erőss Z. Contribution to the Mollusca fauna of Albania. Results of the field trips of the Hungarian Natural History Museum between 1992 and 2007. Schr Malakozool. 2009;25:3-21.

82. European Environment Agency. Disclaimer 2019 status of the network. https://natura2000.eea.europa.eu/. Accessed 21 May 2020.

83. Yamaguchi N, Kitchener A, Driscoll C, Nussberger B. Felis silvestris. In: The IUCN red list of threatened species; 2015:eT60354712A50652361. http:// doi.org/10.2305/IUCN

84. Migli D, Astaras C, Youlatos D. Predicting habitat suitability for the European wildcat Felis silvestris silvestris in Greece. In: 14th International Congress on the Zoogeography and Ecology of Greece and Adjacent Regions (ICZEGAR), 27-30 June 2019, Thessaloniki, Greece; 2019.
85. Lecis R, Pierpaoli M, Biro Z, Szemethy L, Ragni B, Vercillo F, et al. Bayesian analyses of admixture in wild and domestic cats (Felis silvestris) using linked microsatellite loci. Mol Ecol. 2006;15:119-31.

86. Mattucci F, Oliveira R, Bizzarri L, Vercillo F, Anile S, Ragni B, et al. Population genetic structure of wildcats (Felis silvestris) in Italy. Ecol Evol. 2013:3:2443-58.

87. Falsone L, Brianti E, Gaglio G, Napoli E, Anile S, Mallia E, et al. The European wildcats (Felis silvestris silvestris) as reservoir hosts of Troglostrongylus brevior (Strongylida: Crenosomatidae) lungworms. Vet Parasitol. 2014;205:193-8.

88. Morgan ER, Shaw SE, Brennan SF, De Waal TD, Jones BR, Mulcahy G. Angiostrongylus vasorum: a real heartbreaker. Trends Parasitol. 2005;21:49-51.

89. Eleni C, De Liberato C, Azam D, Morgan ER, Traversa D. Angiostrongylus vasorum in wolves in Italy. Int J Parasitol Parasites Wildl. 2014;3:12-4.

90. Morgan E, Shaw S. Angiostrongylus vasorum infection in dogs: continuing spread and developments in diagnosis and treatment. J Small Anim Pract. 2010;51:616-21.

91. Jefferies R, Shaw S, Willesen J, Viney M, Morgan E. Elucidating the spread of the emerging canid nematode Angiostrongylus vasorum between Palaearctic and Nearctic ecozones. Infect Genet Evol. 2010:10:561-8.

92. Jefferies R, Vrhovec MG, Wallner N, Catalan DR. Aelurostrongylus abstrusus and Troglostrongylus sp. (Nematoda: Metastrongyloidea) infections in cats inhabiting Ibiza, Spain. Vet Parasitol. 2010;173:344-8.

93. Saeed I, Maddox-Hyttel C, Monrad J, Kapel CM. Helminths of red foxes (Vulpes vulpes) in Denmark. Vet Parasitol. 2006;139:168-79.

94. Diakou A, Dimzas D, Astaras C, Savvas I, Di Cesare A, Morelli S, et al. Clinical investigations and treatment outcome in a European wildcat (Felis silvestris silvestris) infected by cardio-pulmonary nematodes. Vet Parasitol RSR. 2020;19:100357.

95. Di Cesare A, Morelli S, Colombo M, Simonato G, Veronesi F, Marcer F, et al. Is angiostrongylosis a realistic threat for domestic cats? Front Vet Sci. 2020;7:195.

\section{Publisher's Note}

Springer Nature remains neutral with regard to jurisdictional claims in published maps and institutional affiliations.
Ready to submit your research? Choose BMC and benefit from:

- fast, convenient online submission

- thorough peer review by experienced researchers in your field

- rapid publication on acceptance

- support for research data, including large and complex data types

- gold Open Access which fosters wider collaboration and increased citations

- maximum visibility for your research: over $100 \mathrm{M}$ website views per year

At $\mathrm{BMC}$, research is always in progress.

Learn more biomedcentral.com/submissions 